\title{
PENGARUH CHANGE ORDER TERHADAP BIAYA, MUTU, DAN WAKTU PADA PROYEK KONSTRUKSI GEDUNG BERTINGKAT
}

\author{
Hendy Eka Putra ${ }^{1}$ dan Hendrik Sulistio ${ }^{2}$ \\ ${ }^{1}$ Program Studi Sarjana Teknik Sipil, Universitas Tarumanagara, Jl. Letjen S. Parman No.1 Jakarta \\ Hendy.325150141@stu.untar.ac.id \\ ${ }^{2}$ Program Studi Sarjana Teknik Sipil, Universitas Tarumanagara, Jl. Letjen S. Parman No.1 Jakarta \\ hendriks@ft.untar.ac.id
}

Masuk: 18-07-2020, revisi: 28-07-2020, diterima untuk diterbitkan: 02-11-2020

\begin{abstract}
The implementation of the construction project caused miscommunication, this made the contract became a reference during implementation. In the implementation of construction projects, there are often changes that not according to contract, for example: work volume changes, specifications changes, type or method of work changes, schedules changes, design changes, and others. These changes are commonly known as change orders. There are several things that cause a change order, for example: incompletable contract, design does not fit in the field, unsupportive weather, and others. This research is to determine the effect of change order in the aspects of cost, quality, and time in multistorey building construction projects. Researchers used data from the responses of respondents consisting of contractors, consultants, and owners. The questionnaire made proposes several aspects of change orders and their effects on cost, quality, and time. Analysis of research data was carried out with the help of the SmartPLS 3.0 application program. The influence of change orders on costs is the lack of costs due to the addition of work items, while on quality is the quality decrease due to additional work volume, and on time is the delay in project completion due to changes in completed work.
\end{abstract}

Keywords: change order; effect of change order; construction project; cost; quality; time

\begin{abstract}
ABSTRAK
Pelaksanaan proyek konstruksi menyebabkan terjadi perbedaan pendapat yang disebabkan oleh pihak yang terlibat, hal ini membuat kontrak menjadi sangat penting dan menjadi acuan selama pelaksanaan. Pada pelaksanaan proyek konstruksi sering terjadi perubahan-perubahan yang akhirnya tidak sesuai dengan kontrak sebelumnya contohnya seperti: perubahan volume pekerjaan, perubahan spesifikasi, perubahan jenis atau metode pekerjaan, perubahan jadwal, perubahan design, dan lain-lain. Perubahan ini umum sekali terjadi dalam proyek konstruksi dan lebih sering dikenal sebagai change order. Ada beberapa hal yang menyebabkan perlunya dilakukan change order, misalnya: kontrak yang dibuat tidak lengkap, design yang ada tidak sesuai dengan kondisi lapangan, cuaca yang tidak mendukung, dan lain-lain. Penelitian ini dilakukan untuk mengetahui besar pengaruh change order dalam aspek biaya, mutu, dan waktu dalam proyek konstruksi gedung bertingkat. Peneliti menggunakan data dari hasil tanggapan responden yang terdiri dari kontraktor, konsultan, dan pemilik. Kuesioner yang dibuat mengajukan beberapa aspek mengenai change order serta pengaruhnya terhadap biaya, mutu, dan waktu. Analisis data penelitian dilakukan dengan bantuan program aplikasi SmartPLS 3.0. Pengaruh change order terhadap biaya adalah kurangnya biaya akibat penambahan item pekerjaan, sedangkan terhadap mutu adalah menurunnya kualitas bangunan akibat penambahan volume pekerjaan, dan terhadap waktu adalah terjadinya keterlambatan penyelesaian proyek akibat perubahan pekerjaan yang telah selesai.
\end{abstract}

Kata kunci: change order; pengaruh change order; proyek konstruksi; biaya; mutu; waktu

\section{PENDAHULUAN}

Proyek konstruksi adalah suatu rangkaian kegiatan yang dilakukan hanya sekali dan umumnya dalam jangka pendek. Dalam rangkaian kegiatan tersebut, terdapat suatu proses yang mengolah sumber daya proyek menjadi suatu hasil kegiatan yang berupa bangunan. Selain itu proyek konstruksi memiliki 3 (tiga) karakteristik yaitu: bersifat unik, membutuhkan sumber daya (uang, mesin, metoda, dan material), dan membutuhkan organisasi (Ervianto dan Wulfram, 2002). Sebelum dimulainya suatu proyek konstruksi diperlukan adanya kontrak kerja konstruksi. 
Kontrak kerja konstruksi merupakan suatu perjanjian untuk melaksanakan pembangunan dengan persyaratan tertentu yang dibuat oleh pihak pertama sebagai pemilik bangunan dengan pihak kedua sebagai pelaksana pembangunan. Kontrak kerja konstruksi adalah suatu dokumen kontrak yang mengatur hubungan hukum antara pengguna jasa dan penyedia jasa mengenai pelaksanaan pekerjaan konstruksi (Zatika, Hamzah, dan Sonata, 2018). Dimana dalam kontrak inipun diatur tiga hal dasar yang menjadi pertimbangan suatu proyek konstruksi yaitu: biaya, mutu dan waktu. Akan tetapi sering kali proyek mengalami beberapa permasalahan sehingga terjadi ketidaksesuaian dengan rencana maka perlu dilakukan perubahan. Hampir seluruh proyek konstruksi yang ada di Indonesia mengalami terjadinya perubahan kontrak, baik diselenggarakan oleh pemerintah maupun swasta (Sulistio dan Waty, 2008). Perubahan yang terjadi ini dapat berupa penambahan atau pengurangan volume maupun pekerjaan yang lazimnya disebut dengan istilah change order.

Change order adalah Perubahan yang terjadi pada saat pelaksanaan proyek, dimana perubahan ini disebabkan oleh adanya perpanjangan waktu, penambahan ataupun pengurangan nilai kontrak karena adanya revisi desain (Jr. dan Walters, 2011). Menurut Levy (2002) change order adalah sebuah permintaan secara tertulis yang ditandatangani oleh arsitek, kontraktor, dan pemilik yang dibuat setelah kontrak diterbitkan, yang mempunyai kuasa untuk mengubah ruang lingkup pekerjaan atau melakukan penyesuaian pada nilai kontrak dan waktu penyelesaian pekerjaan. Pengertian lain dari change order adalah surat kesepakatan antara pemilik dan kontraktor untuk menegaskan adanya revisi-revisi rencana dan jumlah kompensasi biaya kepada kontraktor yang terjadi pada saat pelaksanaan konstruksi, setelah penandatanganan kontrak kerja antara pemilik dan kontraktor (Fisk dan Reynolds, 2006).

Change order dapat disebabkan oleh banyak faktor. Menurut Diekmann dan Nelson (1985) change order dipengaruhi $30 \%$ oleh klien dan $65 \%$ oleh konsultan sedangkan faktor lain hanya mempengaruhi $5 \%$.

1. Penyebab yang disebabkan klien:

1) perubahan ruang lingkup dan jadwal proyek

2) kesulitan keuangan

3) tujuan proyek yang tidak mencukupi

4) perubahan spesifikasi dan penggantian bahan

2. Penyebab yang disebabkan konsultan:

1) perubahan dalam desain

2) kesalahan dan kelalaian pada pelaksanaan

3) dokumen kontrak yang saling bertentangan

4) kompleksitas desain

5) tidak cukup detail gambar toko dan ruang lingkup pekerjaan untuk kontraktor

3. Faktor lain yang dimaksud:

1) fluktuasi cuaca

2) kondisi ekonomi negara dan peraturan pemerintah

3) masalah yang tidak terduga

Keane, Sertyesilisk, dan Ross (2010) mengelompokan penyebab change order berdasarkan pihak yang berkontrak, yaitu change order yang terkait dengan pemilik, kontraktor, dan konsultan. Selanjutnya change order yang tidak disebabkan oleh pihak yang berkontrak masuk kedalam kelompok "variabel lainnya".

1. Change order terkait pemilik dapat muncul karena perubahan ruang lingkup, masalah keuangan pemilik, tujuan proyek yang tidak memadai penggantian bahan atau prosedur, hambatan proses pengambilan keputusan, pemilik yang keras kepala, dan perubahan spesifikasi oleh pemilik. Hal ini dijelaskan secara singkat sebagai berikut:

1) Perubahan ruang lingkup: Perubahan rencana atau ruang lingkup proyek adalah salah satu penyebab paling signifikan dalam konstruksi, dan biasanya merupakan hasil dari kurangnya perencanaan pada tahap desain, atau karena kurangnya keterlibatan pemilik dalam fase desain.

2) Masalah keuangan pemilik: Masalah keuangan pemilik dapat mempengaruhi kemajuan dan kualitas proyek. Masalah ini dapat menyebabkan perubahan pada jadwal kerja dan spesifikasi, yang mempengaruhi kualitas konstruksi.

3) Tujuan proyek yang tidak jelas: Tujuan proyek yang tidak jelas dapat menyebabkan perubahan dalam proyek konstruksi

4) Penggantian bahan atau prosedur: Penggantian bahan atau prosedur dapat menyebabkan perubahan selama tahap konstruksi.

5) Hambatan proses pengambilan keputusan: Pengambilan keputusan yang cepat adalah faktor penting 
untuk keberhasilan proyek

6) Sifat keras kepala pemilik: Sebuah proyek pembangunan adalah hasil dari usaha para profesional yang terlibat, yang harus bekerja dalam berbagai bidang dalam proyek. Jika pemiliknya keras kepala maka ini bisa menyebabkan perubahan besar pada tahap akhir proyek.

7) Perubahan spesifikasi oleh pemilik: Perubahan spesifikasi dalam proyek konstruksi yang tidak sesuai dengan tujuan proyek.

2. Change order terkait konsultan, konsultan dapat meminta perubahan karena perubahan desain oleh konsultan, kesalahan atau kelalaian dalam desain, masalah pada dokumen kontrak, perubahan teknologi, rekayasa nilai, kurangnya koordinasi, kompleksitas desain, detail gambar kerja yang tidak memadai, pengetahuan yang buruk tentang bahan dan peralatan yang tersedia, kurangnya data yang dibutuhkan konsultan, detail desain yang ambigu, dan perubahan dalam spesifikasi oleh konsultan. Hal ini dijelaskan secara singkat sebagai berikut:

1) Perubahan dalam desain oleh konsultan: Perubahan dalam desain untuk perbaikan oleh konsultan adalah hal yang normal di kalangan profesional.

2) Kesalahan dan kelalaian dalam desain: Kesalahan dan kelalaian dalam desain adalah penyebab signifikan penundaan proyek. Tergantung pada waktu kesalahan dalam proyek.

3) Masalah pada dokumen kontrak: Masalah pada dokumen kontrak dapat menyebabkan salah tafsir terhadap kontrak yang sebenarnya. Sangat penting dokumen kontrak itu jelas dan tepat. Detail dalam dokumen kontrak yang tidak mencukupi dapat mengakibatkan keterlambatan penyelesaian proyek atau menyebabkan perubahan biaya.

4) Perubahan teknologi: Perubahan teknologi berpotensi menghasilkan change order pada proyek. Kemunculan teknologi baru dapat memengaruhi metode konstruksi dan proses konstruksi.

5) Rekayasa nilai: Rekayasa nilai sebaiknya dilakukan secara ideal selama fase desain. Rekayasa nilai yang dilakukan selama tahap konstruksi dapat menyebabkan perubahan.

6) Kurangnya koordinasi: Kurangnya koordinasi antar pihak dapat menyebabkan perubahan besar dan dampak buruk pada proyek, menyebabkan ketidakpuasan pemilik, pengerjaan ulang, dan perubahan.

7) Kompleksitas desain: Desain kompleks membutuhkan keterampilan dan metode konstruksi. Kompleksitas mempengaruhi alur kegiatan konstruksi, sedangkan desain yang lebih sederhana memerlukan pekerjaan konstruksi relatif mudah ditangani.

8) Detail gambar kerja yang tidak memadai: Untuk menyampaikan detail yang lengkap, konsep desain proyek, gambar kerja harus jelas dan ringkas. Gambar kerja yang tidak detail dapat menyebabkan salah tafsir, menyebabkan change order dalam proyek.

9) Kurang pengetahuan tentang bahan dan peralatan yang tersedia: Pengetahuan mengenai bahan dan peralatan yang tersedia merupakan faktor penting untuk mengembangkan desain yang komprehensif. Jika konsultan memiliki pengetahuan yang buruk tentang bahan yang tersedia atau peralatan yang dapat digunakan dalam proses konstruksi, perubahan lebih mungkin terjadi selama fase konstruksi.

10) Kurangnya data yang diperlukan konsultan: Kurangnya data dapat mengakibatkan salah tafsir tentang keadaan sebenarnya dari proyek. Jika tidak ada cukup data yang tersedia untuk konsultan maka desainnya lebih didasarkan pada persepsi konsultan itu sendiri dari keadaan sebenarnya di proyek.

11) Detail desain yang ambigu: Desain yang lebih jelas cenderung lebih mudah dipahami. Ambigu dalam desain dapat menyebabkan salah tafsir dan kebutuhan untuk pekerjaan ulang, yang akan menunda proyek dan meningkatkan biaya.

12) Desain yang tidak memadai: Desain yang tidak memadai dapat sering menjadi penyebab perubahan dalam proyek konstruksi.

13) Perubahan spesifikasi oleh konsultan: Perubahan spesifikasi dalam proyek konstruksi dengan tidak memperhatikan tujuan proyek. Perubahan spesifikasidapat mengakibatkan perubahan pada proyek, yang menyebabkan keterlambatan dan peningkatan biaya keseluruhan.

3. Change order terkait dengan kontraktor dapat terjadi karena kurangnya keterlibatan dalam desain, tidak tersedianya peralatan, kurangnya keterampilan, kesulitan keuangan kontraktor, profitabilitas yang diinginkan, perbedaan kondisi lapangan, pengerjaan yang buruk, tidak terbiasa dengan kondisi lokal, konstruksi jalur cepat, proses pengadaan yang buruk, kurangnya komunikasi, keterlambatan pengadaan, desain dan teknologi yang kompleks, dan kurangnya perencanaan strategis. Hal ini dijelaskan sebagai berikut:

1) Kurangnya keterlibatan dalam desain: Keterlibatan kontraktor dalam desain dapat membantu dalam mengembangkan desain yang lebih baik dengan mengakomodasi ide-ide kreatif dan praktisnya. Perubahan dapat terjadi karena kontraktor tidak terlibat dalam tahap desain proyek.

2) Ketidaktersediaan peralatan: Ketidaktersediaan peralatan adalah masalah pengadaan yang dapat 
mempengaruhi penyelesaian proyek.

3) Kurangnya keterampilan: Tenaga kerja terampil adalah salah satu yang sumber daya utama yang dibutuhkan untuk proyek berteknologi. Perubahan dan penundaan dapat terjadi karena kekurangan tenaga kerja terampil.

4) Kesulitan keuangan kontraktor: Konstruksi padat karya. Kontraktor telah dibayar atau tidak, upah pekerja tetap harus dibayar. Biasanya seorang kontraktor mengalami kesulitan keuangan selama berlangsungnya proyek, perubahan dapat terjadi, kualitas dan kemajuan proyek mungkin sangat terpengaruh.

5) Profitabilitas yang diinginkan: Variasi dapat terjadi karena yang diinginkan kontraktor utama yang melaksanakan pekerjaan adalah profitabilitas. Perubahan dianggap sebagai sumber umum pekerjaan tambahan untuk kontraktor. Perubahan dapat dilihat sebagai imbalan finansial tambahan untuk kontraktor.

6) Perbedaan kondisi lapangan: Kondisi lapangan yang berbeda dapat menyebabkan terjadinya perubahan. Misalnya kondisi tanah mungkin berbeda dari yang diharapkan oleh kontraktor, atau mungkin ada masalah pada konstruksi substruktur yang tidak dapat diperoleh dari penyelidikan lapangan.

7) Pengerjaan yang buruk: Pengerjaan yang rusak dapat menyebabkan pembongkaran dan pengerjaan ulang dalam proyek konstruksi. Hal ini dapat menyebabkan keterlambatan dan peningkatan biaya.

8) Tidak terbiasa dengan kondisi lokal: Adaptasi dengan kondisi lokal merupakan faktor penting untuk keberhasilan penyelesaian proyek konstruksi. Kontraktor yang tidak terbiasa dengan kondisi setempat, akan sulit untuk melakukan pekerjaan, yang akan menyebabkan change order dan penundaan penyelesaian proyek.

9) Konstruksi jalur cepat: Konstruksi jalur cepat membutuhkan sistem terorganisir untuk melaksanakan kegiatan independen proyek secara bersamaan.

10) Proses pengadaan yang buruk: Keterlambatan pengadaan memiliki beragam efek buruk pada proses lain dalam siklus konstruksi.

11) Kurang komunikasi: Kurangnya koordinasi dan komunikasi antar pihak dapat menyebabkan perubahan besar yang akhirnya berdampak negatif pada proyek, menyebabkan pembongkaran dan pengerjaan ulang yang mempengaruhi kemajuan proyek.

12) Keterlambatan pengadaan jangka panjang: Keterlambatan pengadaan memiliki berbagai efek buruk pada proses lain dalam siklus konstruksi. Kontraktor mungkin perlu mempercepat pembangunan untuk mengejar ketinggalan dengan batas waktu yang ditentukan dalam kontrak. Ini bisa menjadi penyebab perubahan karena meningkatnya biaya dan pekerjaan tambahan.

13) Desain dan teknologi yang kompleks: Desain dan teknologi yang kompleks membutuhkan interpretasi terperinci oleh desainer agar membuatnya dapat dipahami oleh kontraktor. Desain yang kompleks dapat menghambat aliran proses konstruksi, menyebabkan perubahan dan keterlambatan penyelesaian proyek.

14) Kurangnya perencanaan strategis: Perencanaan strategis yang tepat adalah faktor penting keberhasilan penyelesaian proyek. Kurangnya perencanaan strategis adalah penyebab umum change order dalam proyek di mana konstruksi dimulai sebelum desain diselesaikan.

4. Penyebab change order yang tidak terkait langsung dengan peserta dalam proyek konstruksi termasuk kondisi cuaca, kesehatan dan keselamatan, perubahan kondisi ekonomi, faktor sosial budaya, dan tak terduga masalah. Ini dijelaskan secara singkat sebagai berikut:

1) Kondisi cuaca: Kondisi cuaca buruk dapat mempengaruhi kegiatan luar dalam proyek konstruksi. Cuaca memiliki efek yang merugikan, keterlambatan dalam proses konstruksi, perubahan yang terjadi mengkompensasi keterlambatan dan biaya tambahan dalam pekerjaan.

2) Kesehatan dan keselamatan: Keselamatan adalah faktor penting untuk kesuksesan penyelesaian proyek bangunan. Ketidakpatuhan terhadap peraturan keselamatan dapat menyebabkan perubahan dalam aspek desain proyek.

3) Perubahan kondisi ekonomi: Kondisi ekonomi adalah satu dari faktor-faktor yang berpengaruh yang dapat mempengaruhi proyek konstruksi. Perubahan kondisi ekonomi selama proyek konstruksi menyebabkan change order, untuk mengurangi biaya pembangunan.

4) Faktor sosial budaya: Kurangnya koordinasi antara profesional dengan latar belakang sosial budaya yang berbeda. Change order dapat terjadi sebagai akibat dari hal ini dan perubahan mungkin diperlukan untuk tim proyek.

5) Masalah yang tidak terduga: Kondisi tidak terduga biasanya dihadapi oleh para profesional di industri konstruksi. Kondisi ini, jika tidak diselesaikan, dapat menghasilkan change order pada proyek. 
Keane, Sertyesilisk, \& Ross (2010) mengklasifikasikan dampak change order dalam lima kategori: biaya, kualitas, waktu, efek terkait organisasi, dan efek lainnya.

1. Efek yang berhubungan dengan biaya: Keterlambatan pembayaran dapat, mengarah ke peningkatan biaya proyek karena tarif bunga. Change order memerlukan prosedur pemrosesan, dokumen, dan ulasan sebelum dapat diimplementasikan, yang akan menyebabkan peningkatan biaya overhead. Pembayaran tambahan untuk kontraktor dapat menjadi efek potensial dari change order pada proyek konstruksi. Change order dianggap sebagai pekerjaan tambahan untuk kontraktor.

2. Efek terkait kualitas: Change order selama proyek dapat memengaruhi kualitas. Change order, jika sering, dapat menurunkan kualitas kerja. Change order dapat memengaruhi waktu penyelesaian proyek dan dapat menyebabkan percepatan proses konstruksi yang mempengaruhi kualitas.

3. Efek terkait waktu: Change order yang terjadi saat konstruksi sedang berlangsung atau bahkan selesai biasanya menyebabkan pengerjaan ulang dan keterlambatan penyelesaian proyek. Change order selama proyek dapat mempengaruhi kemajuan proyek, yang pada selanjutnya dapat mempengaruhi pembayaran kepada subkontraktor, biasanya karena kontraktor utama tidak dapat membayar sub kontraktor sampai mereka telah dibayar oleh pemiliknya sendiri. Keterlambatan jadwal penyelesaian adalah hal yang sering terjadi pada proyek konstruksi. Keterlambatan logistik dapat terjadi karena change order membutuhkan material dan peralatan baru.

4. Efek terkait organisasi: Perselisihan tentang change order dan klaim tidak bisa dihindari dan klausa change order sering menjadi sumber perselisihan dalam proyek. Perubahan konstruksi adalah sumber utama sengketa konstruksi. Change order pada akhirnya dapat memengaruhi hubungan profesional pada proyek konstruksi, yang mengarah ke perselisihan dan penundaan lebih lanjut. Klaim dan perselisihan dapat berdampak buruk pada reputasi perusahaan, dan juga dapat membuat perselisihan profesional lebih mungkin terjadi. Perubahan dapat memengaruhi kondisi keselamatan dalam proyek konstruksi. Change order mungkin membutuhkan metode dan tindakan pencegahan tambahan. Percepatan pekerjaan dapat menyebabkan kondisi keselamatan yang buruk. Selanjutnya, keterlambatan penyelesaian konstruksi, kegagalan dalam memenuhi persyaratan kualitas, dan meningkatnya resiko kecelakaan dapat merusak reputasi perusahaan, memburuknya hubungan profesional dan menyebabkan perselisihan di antara para profesional.

5. Efek lain: Change order dapat memengaruhi kemajuan proyek tanpa menyebabkan keterlambatan. Efek change order terkait waktu yang merugikan dapat dikompensasi dengan percepatan penyelesaian pekerjaan.

Dalam penelitiannya Yadeta (2016) menyimpulkan 15 dampak yang terjadi sebagai pengaruh dari change order yaitu:

1. Penambahan biaya proyek

2. Kenaikan biaya overhead

3. Terlambatnya pembayaran

4. Penambahan biaya untuk kontraktor

5. Penurunan kualitas pekerjaan

6. Pekerjaan jadi terganggu

7. Menurunnya produktivitas

8. Keterlambatan pengadaan material

9. Pengerjaan ulang dan pembongkaran

10. Keterlambatan logistic

11. Penyelesaian proyek tertunda

12. Merusak reputasi

13. Konflik antarpihak

14. Terjadinya sengketa

15. Standar keamanan menurun

Menurut Barrie dan Paulson (1992) besar dampak atau pengaruh yang terjadi dari change order tergantung dari besarnya change order yang dilakukan dari kontrak awal.

1. Selama perubahan merupakan skala kecil dalam kontrak yaitu kurang dari $10 \%$ maka perubahan tersebut masih bisa ditoleransi dan hanya ada penyesuaian terhadap waktu saja.

2. Ketika change order sudah mencapai $15 \%$ dari nilai kontrak awal, maka akan berdampak terhadap waktu dan biaya sangat relatif, tergantung keahlian dari manajemen kontraktor untuk mengelolah perubahan tersebut.

3. Ketika change order mencapai $20 \%$ dari kontrak awal, maka hal ini akan sangat mempengaruhi performance kontraktor. 


\section{METODE PENELITIAN}

\section{Kerangka penelitian}

Kerangka penelitian yang dijadikan sebagai pedoman penelitian ini dapat dilihat pada Gambar 1 berikut.

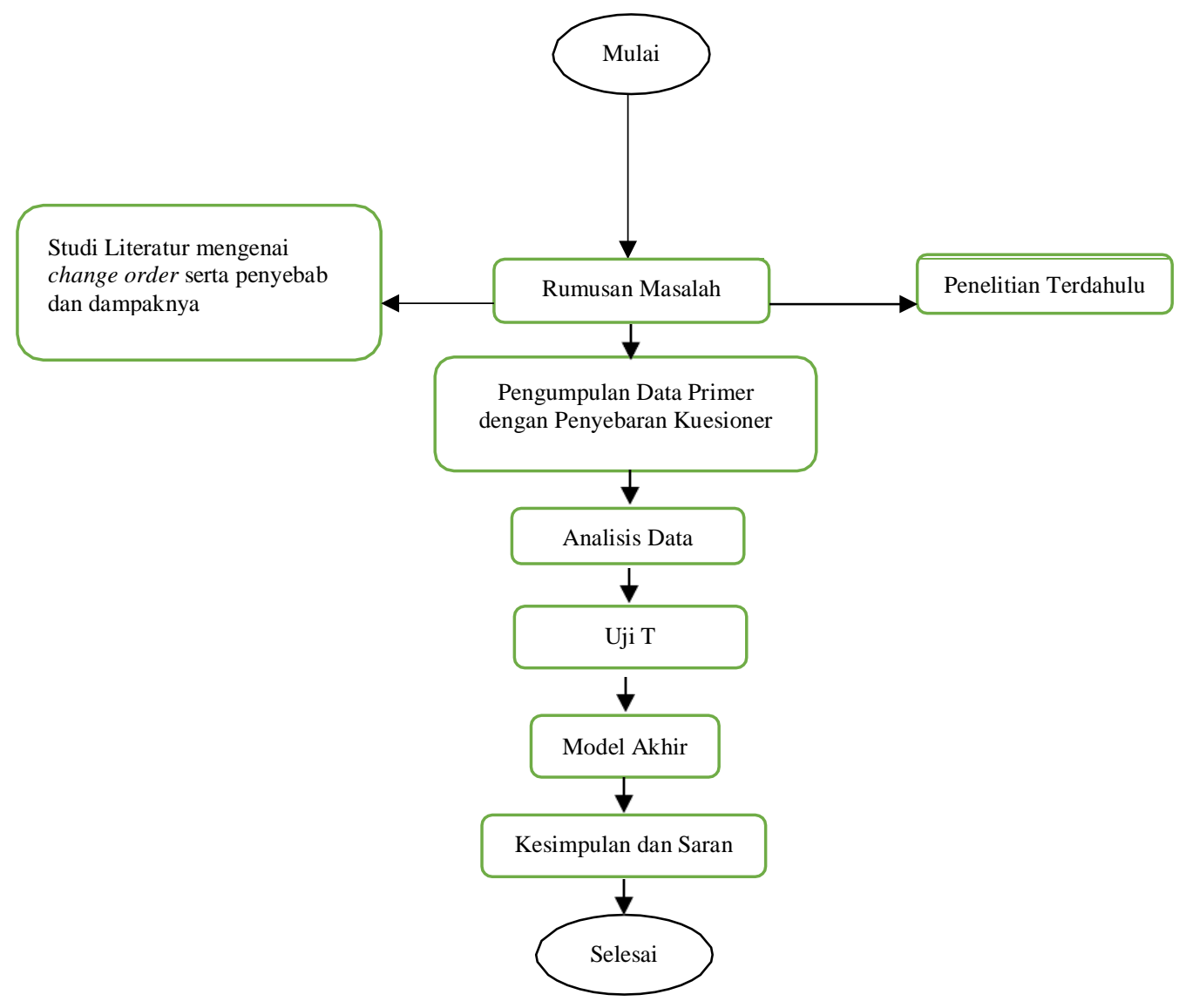

Gambar 1. Kerangka penelitian

\section{Studi literatur}

Studi literatur ini penting dilakukan untuk membantu penulis lebih mendalami dan memahami objek serta metode yang akan digunakan dalam penelitian. Hasil dari studi literatur ini nantinya akan dijadikan sebagai acuan untuk penelitian ini. Penulis melakukan studi literatur melalui:

1. Jurnal-jurnal

2. Buku-buku

\section{Kuesioner}

Kuesioner penelitian dibuat dengan menggunakan metode modifikasi yang diambil dari kuesioner penelitian Yadeta (2016) yang kemudian digolongkan menjadi 3 kategori, yaitu:

1. Biaya

2. Mutu

3. Waktu

Setelah itu ditambahkan beberapa indikator penyebab terjadinya change order antara lain:

1. Perubahan design

2. Perubahan pada pekerjaan yang telah selesai

3. Kontrak yang tidak lengkap 


\section{Populasi dan sampel penelitian}

Populasi pada penelitian ini ialah setiap pihak yang pernah / sedang terlibat dalam proyek konstruksi gedung bertingkat di kawasan Jabodetabek. Alasan dari pemilihan lokasi penelitian dikarenakan oleh banyaknya jumlah proyek konstruksi gedung bertingkat yang telah atau sedang berlangsung di lokasi tersebut sehingga pengumpulan data menjadi lebih mudah. Sedangkan, sampel penelitian ini ialah kontraktor, konsultan perencana, dan owner yang berada di kawasan Jabodetabek. Alasan dari pemilihan sampel karena pihak-pihak tersebut merupakan pihak yang memiliki kuasa dan bertanggung jawab terhadap suatu perubahan pekerjaan dalam proyek konstruksi.

\section{Pengumpulan data}

Pada tahap pengumpulan data dilakukan melalui penyebaran kuesioner online google form kepada setiap pihak yang sedang dan pernah terlibat dalam proyek konstruksi gedung bertingkat di Jabodetabek yang kemudian dijadikan sebagai sampel.

Pengukuran nilai kuesioner akan menggunakan teknik pengukuran dengan skala likert. Skala yang digunakan sebagai berikut: Keterangan untuk skala pengukuran tingkat frekuensi dampak change order pada proyek konstruksi:

1. Tidak pernah ada

2. Sangat Jarang

3. Jarang

4. Sering

5. Selalu ada

\section{Pengolahan data}

Pada tahap ini data yang didapat kemudian diolah dan dicatat kedalam bagan excel dikarenakan variabel dalam penelitian adalah variabel laten maka analisa dilakukan dengan alat bantu partial least square (PLS) untuk mengetahui pengaruh yang ditimbulkan change order terhadap biaya, mutu, dan waktu.

\section{Metode analisis data}

Analisi data dilakukan dengan memanfaatkan aplikasi SmartPLS 3.0. Pengunaan dikarenakan Partial Least Square dapat menganalisis sekaligus konstruk yang dibentuk dengan indikator refleksif dan indikator formatif dan hal ini tidak mungkin dijalankan dalam Structural Equation Model (SEM) karena akan terjadi unidentified model. Alasan lainnya PLS juga dapat digunakan untuk menkonfirmasi teori sehingga memudahkan uji hipotesis, PLS juga dapat digunakan untuk menjelaskan korelasi hubungan antar variabel laten.

\section{Uji statistik deskriptif}

Penelitian ini menggunakan teknik analisis statistik deskriptif yang bertujuan untuk menjelaskan atau memberikan informasi demografi responden penelitian serta deskripsi mengenai variabel penelitian.

\section{Uji hipotesis}

Pengujian hipotesis dilakukan dengan pendekatan Structural Equation Model (SEM) menggunakan software Partial Least Square (PLS). PLS adalah model persamaan struktural (SEM) yang berbasis komponen atau varian (variance). Menurut Ghozali (2014) PLS merupakan pendekatan alternatif yang bergeser dari pendekatan SEM berbasis covariance menjadi berbasis varian. SEM yang berbasis kovarian umumnya menguji kausalitas/teori, sedangkan PLS lebih bersifat predictive model.

PLS merupakan metode analisis yang powerfull (Wold, 1985 dalam Ghozali, 2014) karena tidak didasarkan pada banyak asumsi, misalnya data harus terdistribusi normal dan sampel tidak harus besar. Selain dapat digunakan untuk mengkonfirmasi teori, PLS juga dapat digunakan untuk menjelaskan ada tidaknya hubungan antar variabel laten. Tujuan PLS adalah membantu peneliti untuk melakukan prediksi. Dalam penelitian ini terdapat 3 hipotesis yang akan diuji:

1. Change order berpengaruh signifikan terhadap biaya pada proyek konstruksi gedung bertingkat.

2. Change order berpengaruh signifikan terhadap mutu pada proyek konstruksi gedung bertingkat.

3. Change order berpengaruh signifikan terhadap waktu pada proyek konstruksi gedung bertingkat.

\section{Lokasi penelitian}

Penelitian ini dilakukan daerah Jabodetabek. Sebab pada wilayah tersebut banyak proyek yang sudah maupun sedang berlangsung maka pengumpulan data lebih mudah dan hasil yang didapat lebih akurat. 


\section{HASIL DAN PEMBAHASAN}

\section{Karakteristik responden}

Responden pada penelitian ini berjumlah 35 orang dan dapat dilihat pada Gambar 2 bahwa responden dengan pengalaman kerja 1-5 tahun berjumlah 13 responden, 5-10 tahun berjumlah 10 responden, 10-15 tahun berjumlah 5 responden, 15-20 tahun berjumlah 3 responden, dan $\geq 20$ tahun berjumlah 4 responden

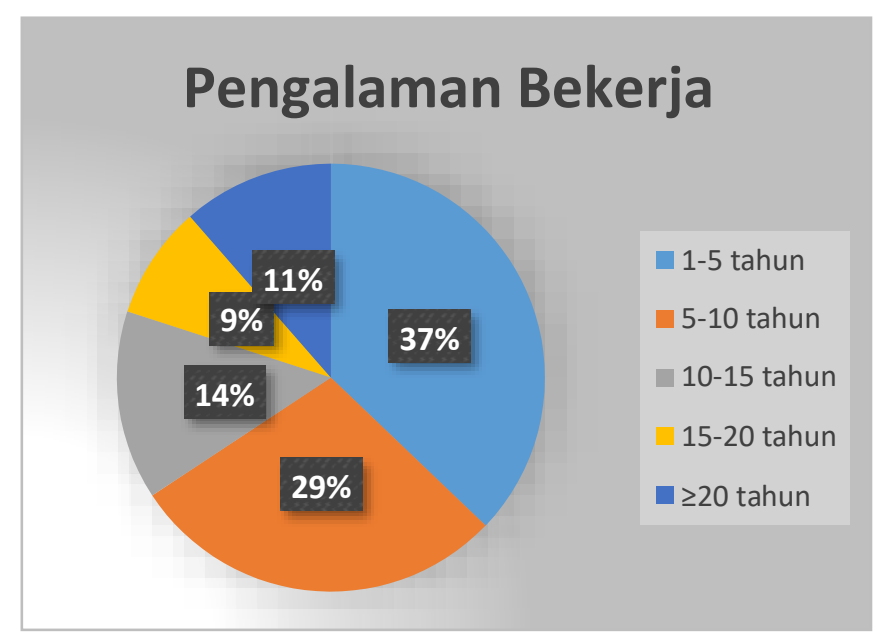

Gambar 2. Karakteristik responden berdasarkan pengalaman bekerja

\section{Perancangan model}

Dapat dilihat pada Gambar 3 bahwa penelitian ini memiliki 1 variabel eksogen (exogenous) atau variabel yang mempengaruhi dengan 3 variabel endogen (endogenous)/ variabel yang dipengaruhi berikut keterangan variabel laten beserta indikatornya:

1. Change order (Y)
a. Perubahan design (Y1)
b. Perubahan pekerjaan yang telah selesai (Y2)
c. Perubahan kondisi di lapangan (Y3)

2. Biaya (X1)
a. Penambahan biaya proyek (X1.1)
b. Penambahan biaya overhead (X1.2)
c. Keterlambatan pembayaran (X1.3)
d. Penambahan biaya untuk kontraktor (X1.4)

3. Mutu (X2)
a. Penurunan kualitas pekerjaan (X2.1)
b. Pekerjaan terganggu (X2.2)

4. Waktu (X3)
a. Penurunan produktivitas (X3.1)
b. Keterlambatan material (X3.2)
c. Pengerjaan ulang dan pembongkaran (X3.3)
d. Keterlambatan logistik (X3.4)
e. Penyelesaian proyek tertunda (X3.5) 


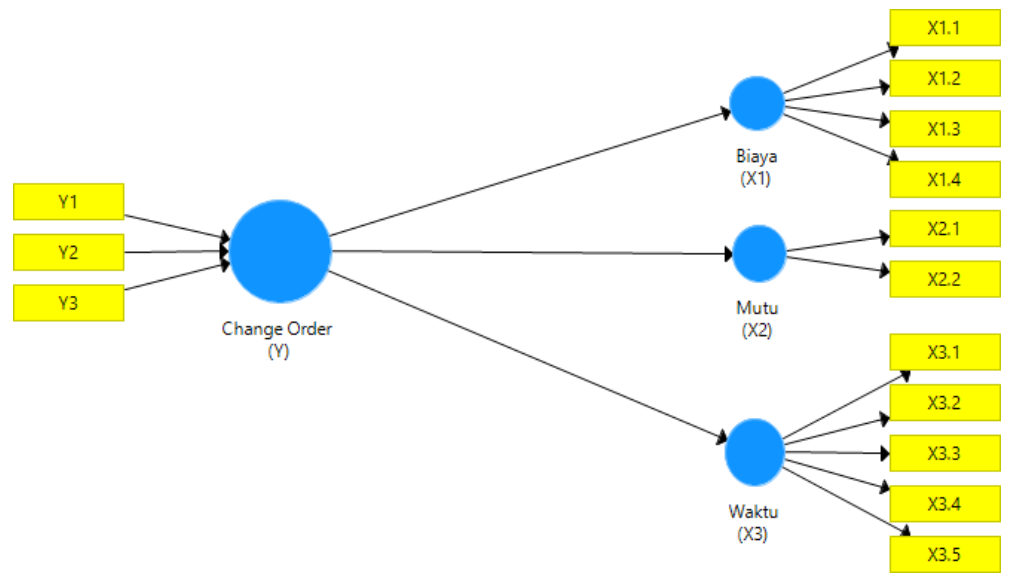

Gambar 3. Path modeling

\section{Perhitungan PLS algorithm}

Pada bagian ini dilakukan kalkulasi dengan PLS Algorithm seperti dapat dilihat pada Gambar 4, kemudian dilakukan pengujian pada outer model dan inner model untuk mengetahui apakah data yang digunakan sudah valid atau belum. Apabila terdapat pengujian yang tidak valid maka perlu diperbaiki dan dilakukan perhitungan ulang. Namun, bila hasil pengujian sudah valid dilanjutkan ketahap selanjutnya.

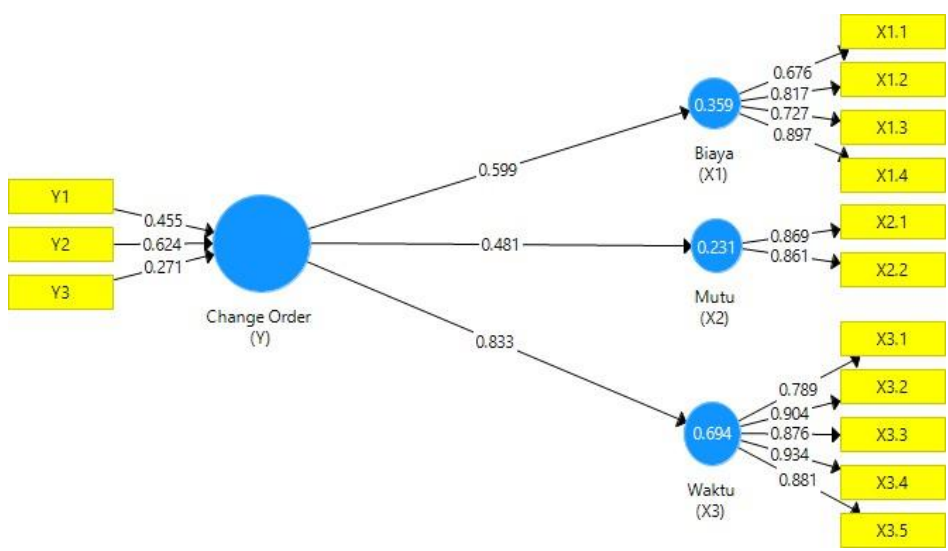

Gambar 4. Hasil perhitungan dengan PLS Algorithm

\section{Uji T model akhir dengan bootstrapping}

Setelah pengujian yang dilakukan valid semua dilanjutkan dengan uji T untuk mengetahui nilai signifikansi indikator terhadap variabel latennya. Perhitungan T statistik dibantu dengan bootstrapping pada SmartPLS 3.0. Supaya nilai T yang didapatkan stabil maka diharuskan menggunakan subsamples lebih besar dari 500. Pada penelitian ini dilakukan bootstraping dengan jumlah subsamples sebesar 5000 untuk menjamin kestabilan nilai T yang didapatkan. Persentase kesalahan $(\alpha)$ pada penelitian ini adalah 5\%, diharapkan tingkat kepercayaan untuk mendapatkan persentase kebenaran penelitian adalah sebesar 95\%. Untuk mengetahui signifikansi perlu dibandingkan nilai T tabel dengan T statistik / T hitung, T tabel untuk Persentase kesalahan 5\% adalah 1,96. Maka T hitung harus $>1,96$ agar signifikan namun apabila T hitung $<1,96$ hasil yang didapat adalah tidak signifikan.

\section{Outer model}

Pada tahap ini model yang sudah dikalkuklasi dengan PLS Algorithm dilakukan pengujian pada outer model untuk indikator reflektif yang meliputi: convergent validity, discriminant validity, average variance extracted, dan construct reliability. Selanjutnya, untuk indikator formatif meliputi: significance of weights dan multicollinearity.

Berikut merupakan hasil pada uji outer model: 
1. Indikator Reflektif

a. Convergent Validity

Seperti dapat dilihat Tabel 1 dan Tabel 2, maka dapat disimpulkan seluruh indikator pada variabel laten mampu menjelaskan variabelnya masing-masing dan sudah memiliki pengaruh yang signifikan terhadap variabelnya, maka indikator yang ada sudah valid.

Berikut merupakan hasil Outer Loadings dengan PLS Algorithm dan dengan Bootstrapping:

Tabel 1. Outer Loadings dengan PLS Algorithm

\begin{tabular}{|c|c|c|c|c|}
\hline & Biaya_(X1) & $\begin{array}{c}\text { Change } \\
\text { order_(Y) }\end{array}$ & Mutu_(X2) & Waktu_(X3) \\
\hline X1.1 & 0,676 & & & \\
\hline X1.2 & 0,817 & & & \\
\hline X1.3 & 0,727 & & & \\
\hline X1.4 & $\mathbf{0 , 8 9 7}$ & & & \\
\hline X2.1 & & & 0,869 & \\
\hline $\mathrm{X} 2.2$ & & & 0,861 & \\
\hline X3.1 & & & & 0,789 \\
\hline X3.2 & & & & 0,904 \\
\hline X3.3 & & & & 0,876 \\
\hline X3.4 & & & & 0,934 \\
\hline X3.5 & & & & $\mathbf{0 , 8 8 1}$ \\
\hline
\end{tabular}

Tabel 2. Outer Loadings dengan Bootstrapping

\begin{tabular}{|c|c|c|c|c|c|}
\hline & $\begin{array}{l}\text { Original } \\
\text { Sample } \\
(\text { (O) }\end{array}$ & $\begin{array}{c}\text { Sample } \\
\text { Mean } \\
(M)\end{array}$ & $\begin{array}{l}\text { Standard } \\
\text { Deviation } \\
\text { (STDEV) }\end{array}$ & $\begin{array}{c}\text { T Statistics } \\
(|O / S T D E V|)\end{array}$ & $P$ Values \\
\hline $\begin{array}{c}\text { X1.1 <- } \\
\text { Biaya_(X1) }\end{array}$ & 0,676 & 0,667 & 0,163 & 4,135 & 0,000 \\
\hline $\begin{array}{c}\text { X1.2 - } \\
\text { Biaya_(X1) }\end{array}$ & 0,817 & 0,773 & 0,221 & 3,688 & 0,000 \\
\hline $\begin{array}{c}\text { X1.3 <- } \\
\text { Biaya_(X1) }\end{array}$ & 0,727 & 0,686 & 0,208 & 3,495 & 0,000 \\
\hline $\begin{array}{c}\text { X1.4 }<- \\
\text { Biaya_(X1) }\end{array}$ & 0,897 & 0,868 & 0,187 & 4,783 & 0,000 \\
\hline $\begin{array}{c}\text { X2.1 <- } \\
\text { Mutu_(X2) }\end{array}$ & 0,869 & 0,843 & 0,151 & 5,743 & 0,000 \\
\hline $\begin{array}{c}\text { X2.2 }<- \\
\text { Mutu_(X2) }\end{array}$ & 0,861 & 0,849 & 0,113 & 7,590 & 0,000 \\
\hline $\begin{array}{c}\text { X3.1 <- } \\
\text { Waktu_(X3) }\end{array}$ & 0,789 & 0,780 & 0,086 & 9,167 & 0,000 \\
\hline $\begin{array}{c}\text { X3.2 <- } \\
\text { Waktu_(X3) }\end{array}$ & 0,904 & 0,903 & 0,036 & 25,441 & 0,000 \\
\hline $\begin{array}{c}\text { X3.3 <- } \\
\text { Waktu_(X3) }\end{array}$ & 0,876 & 0,871 & 0,047 & 18,561 & 0,000 \\
\hline
\end{tabular}


Tabel 3. Outer Loadings dengan Bootstrapping (lanjutan)

\begin{tabular}{cccccc} 
& $\begin{array}{c}\text { Original } \\
\text { Sample } \\
(\boldsymbol{O})\end{array}$ & $\begin{array}{c}\text { Sample } \\
\text { Mean } \\
(\boldsymbol{M})\end{array}$ & $\begin{array}{c}\text { Standard } \\
\text { Deviation } \\
(\text { STDEV })\end{array}$ & $\begin{array}{c}\text { T Statistics } \\
(\mid \text { OSTSTEV })\end{array}$ & P Values \\
\hline $\begin{array}{c}\text { X3.4 <- } \\
\text { Waktu_(X3) }\end{array}$ & 0,934 & 0,932 & 0,022 & $\mathbf{4 3 , 2 0 2}$ & $\mathbf{0 , 0 0 0}$ \\
$\begin{array}{c}\text { X3.5 <- } \\
\text { Waktu_(X3) }\end{array}$ & 0,881 & 0,874 & 0,054 & $\mathbf{1 6 , 3 7 6}$ & $\mathbf{0 , 0 0 0}$ \\
\hline
\end{tabular}

b. Discriminant Validity

Pada Tabel 4 dan Tabel 5 dapat dilihat bahwa nilai loading pada konstruk yang dituju sudah lebih besar dibandingkan dengan konstruk yang lain .

Tabel 4. Cross loadings

\begin{tabular}{|ccccc}
\hline & Biaya_(X1) & $\begin{array}{c}\text { Change } \\
\text { order_(Y) }\end{array}$ & Mutu_(X2) & Waktu_(X3) \\
\hline X1.1 & $\mathbf{0 , 6 7 6}$ & 0,441 & 0,159 & 0,357 \\
\hline X1.2 & $\mathbf{0 , 8 1 7}$ & 0,450 & 0,211 & 0,228 \\
X1.3 & $\mathbf{0 , 7 2 7}$ & 0,435 & 0,338 & 0,319 \\
X1.4 & $\mathbf{0 , 8 9 7}$ & 0,542 & 0,189 & 0,316 \\
X2.1 & 0,239 & 0,421 & $\mathbf{0 , 8 6 9}$ & 0,157 \\
X2.2 & 0,250 & 0,410 & $\mathbf{0 , 8 6 1}$ & 0,499 \\
\hline X3.1 & 0,281 & 0,584 & 0,527 & $\mathbf{0 , 7 8 9}$ \\
X3.2 & 0,467 & 0,792 & 0,295 & $\mathbf{0 , 9 0 4}$ \\
\hline X3.3 & 0,360 & 0,724 & 0,310 & $\mathbf{0 , 8 7 6}$ \\
X3.4 & 0,371 & 0,814 & 0,345 & $\mathbf{0 , 9 3 4}$ \\
\hline X3.5 & 0,205 & 0,716 & 0,221 & $\mathbf{0 , 8 8 1}$ \\
\hline
\end{tabular}

Tabel 5. Fornell-larcker criterion

\begin{tabular}{ccccc}
\hline & Biaya_(X1) & $\begin{array}{c}\text { Change } \\
\text { order_(Y) }\end{array}$ & Mutu_(X2) & Waktu_(X3) \\
\hline Biaya_(X1) & $\mathbf{0 , 7 8 4}$ & & & \\
Mutu_(X2) & 0,282 & 0,481 & $\mathbf{0 , 8 6 5}$ & \\
Waktu_(X3) & 0,388 & 0,833 & 0,376 & $\mathbf{0 , 8 7 8}$ \\
\hline
\end{tabular}

c. Average Variance Extracted (AVE)

Dapat dilihat pada Tabel 6 bahwa semua nilai $A V E$ pada setiap variabel dependen sudah memenuhi kriteria $>0,50$.

Tabel 6. Average Variance Extracted (AVE)

\begin{tabular}{cc}
\hline & Average Variance Extracted $(A V E)$ \\
\hline Biaya_(X1) & 0,614 \\
Mutu_(X2) & 0,748 \\
Waktu_(X3) & 0,771 \\
\hline
\end{tabular}


d. Construct Reliability

Pada Tabel 7 nilai Cronbach Alpha sudah >0,60 untuk semua konstruk.

Berikut ini merupakan hasil Cronbach's Alpha:

Tabel 7. Cronbach's Alpha

\begin{tabular}{cc}
\hline & $\begin{array}{c}\text { Cronbach's } \\
\text { Alpha }\end{array}$ \\
\hline Biaya_(X1) & $\mathbf{0 , 7 8 5}$ \\
Mutu_(X2) & $\mathbf{0 , 6 6 4}$ \\
Waktu_(X3) & $\mathbf{0 , 9 2 5}$ \\
\hline
\end{tabular}

2. Indikator Formatif

a. Significance of weights

Berikut merupakan hasil Outer Weight model awal dapat dilihat pada Tabel 8:

Tabel 8. Outer Weight

\begin{tabular}{|lccccc}
\hline & $\begin{array}{c}\text { Original } \\
\text { Sample } \\
(\boldsymbol{O})\end{array}$ & $\begin{array}{c}\text { Sample } \\
\text { Mean } \\
(\boldsymbol{M})\end{array}$ & $\begin{array}{c}\text { Standard } \\
\text { Deviation } \\
(\text { STDEV })\end{array}$ & $\begin{array}{c}\text { T Statistics } \\
(\mid \text { O/STDEV|) }\end{array}$ & P Values \\
\hline Y1 -> Change order_(Y) & 0,455 & 0,434 & 0,119 & 3,809 & $\mathbf{0 , 0 0 0}$ \\
Y2 -> Change order_(Y) & 0,624 & 0,637 & 0,134 & 4,669 & $\mathbf{0 , 0 0 0}$ \\
Y4 -> Change order_(Y) & 0,271 & 0,265 & 0,116 & 2,339 & $\mathbf{0 , 0 1 9}$ \\
\hline
\end{tabular}

Setelah melihat Tabel 8, maka disimpulkan semua indikator formatif memiliki nilai weight yang signifikan karena T hitung > 1,96.

b. Multicollinearity

Dapat dilihat pada Tabel 9 nilai VIF tidak diantara 5- 10 maka dapat dikatakan bahwa indikator formatif yaitu Y1, Y2, dan Y4 tidak terjadi multicollinearity.

Tabel 9. Collinearity Statistics (VIF)

\begin{tabular}{cc} 
& VIF \\
\hline Y1 & $\mathbf{1 , 3 9 1}$ \\
Y2 & $\mathbf{1 , 1 2 1}$ \\
Y4 & $\mathbf{1 , 5 2 0}$ \\
\hline
\end{tabular}

\section{Inner model}

Pada tahap ini dilakukan pengujian inner model yang mencakup beberapa hal sebagai berikut:

a. $R$ Square pada konstruk endogen

Berikut hasil nilai $R$ square yang dapat dilihat pada Tabel 10:

Tabel 10. $R$ Square

\begin{tabular}{ccc}
\hline & $\boldsymbol{R}$ Square & $\boldsymbol{R}$ Square Adjusted \\
\hline Biaya_(X1) & 0,359 & 0,340 \\
Mutu_(X2) & 0,231 & 0,208 \\
Waktu_(X3) & 0,694 & 0,685 \\
\hline
\end{tabular}

Dari hasil Tabel 10 dapat disimpulkan:

1. Variabel eksogen change order mampu menjelaskan variabel endogen biaya secara kuat ditandai dengan nilai $\mathrm{R}$ square sebesar 0,340 . 
2. Variabel eksogen change order mampu menjelaskan variabel endogen mutu secara moderat ditandai dengan nilai R square sebesar 0,208.

3. Variabel eksogen change order mampu menjelaskan variabel endogen waktu secara kuat ditandai dengan nilai $\mathrm{R}$ square sebesar 0,685 .

b. Estimate for Path Coefficients

Berikut merupakan hasil path coeffisients yang didapat setelah uji T dapat dilihat pada Tabel 11:

Tabel 11. Path coefficients dengan Bootstrapping

\begin{tabular}{cccccc}
\hline & $\begin{array}{c}\text { Original } \\
\text { Sample } \\
(\boldsymbol{O})\end{array}$ & $\begin{array}{c}\text { Sample } \\
\text { Mean } \\
(\boldsymbol{M})\end{array}$ & $\begin{array}{c}\text { Standard } \\
\text { Deviation } \\
(\text { STDEV })\end{array}$ & $\begin{array}{c}\text { T Statistics } \\
(\mid \text { OSTDEV|) }\end{array}$ & P Values \\
\hline Change order_(Y) -> Biaya_(X1) & 0,599 & 0,604 & 0,141 & 4,237 & $\mathbf{0 , 0 0 0}$ \\
Change order_(Y) -> Mutu_(X2) & 0,481 & 0,506 & 0,112 & 4,279 & $\mathbf{0 , 0 0 0}$ \\
Change order_(Y) -> Waktu_(X3) & 0,833 & 0,839 & 0,048 & 17,190 & $\mathbf{0 , 0 0 0}$ \\
\hline
\end{tabular}

Dari hasil Tabel 11 dapat disimpulkan:

1. Nilai T hitung biaya adalah 4,237 > 1,96 (T tabel).

2. Nilai T hitung mutu adalah 4,279 >1,96 (T tabel).

3. Nilai T hitung waktu adalah $17,190>1,96$ (T tabel).

c. Prediction relevance ( $Q$ square)

Pada bagian ini untuk mengetahui besaran nilai $\mathrm{Q}^{2}$ perlu dilakukan perhitungan dengan bantuan blindfolding pada SmartPLS 3,0. Hasil tersebut dapt dilihat pada Tabel 12:

Tabel 12. Construct Crossvalidated Redundancy (total)

\begin{tabular}{cccc}
\hline & SSO & SSE & Q $^{2}$ (=1-SSE/SSO) \\
\hline Biaya_(X1) & 140,000 & 113,622 & 0,188 \\
Chane order_(Y) & 105,000 & 105,000 & \\
Mutu_(X2) & 70,000 & 59,589 & 0,149 \\
Waktu_(X3) & 175,000 & 86,792 & 0,504 \\
\hline
\end{tabular}

Dari Tabel 12 dapat dilihat besaran nilai Prediction relevance ( $Q$ square) masing-masing variabel dan dapat disimpulkan:

1. Model sudah memiliki kapabilitas relevansi prediktif besar untuk biaya $(0,188)$.

2. Model sudah memiliki kapabilitas relevansi prediktif sedang untuk mutu $(0,149)$.

3. Model sudah memiliki kapabilitas relevansi prediktif besar untuk waktu $(0,504)$.

\section{Uji hipotesis}

Pada tahap ini akan dilakukan pengujian terhadap hipotesis penelitian yang sudah dibuat sebelumnya dengan bantuan hasil analisis dari SmartPLS 3.0 sebagai berikut:

1. Hipotesis 1

Ho = change order tidak berpengaruh signifikan terhadap biaya pada proyek konstruksi gedung bertingkat.

$\mathrm{Ha}=$ change order berpengaruh signifikan terhadap biaya pada proyek konstruksi gedung bertingkat.

Hasil analisis path modeling dapat dilihat pada Tabel 11 yang menunjukan nilai hubungan change order terhadap biaya sebesar 0,599 dan nilai T hitung biaya adalah sebesar 4,237 yang menandakan memiliki nilai yang lebih besar dari T tabel yaitu 1,96. Sehingga, T hitung > T tabel maka terjadi pengaruh signifikan terhadap biaya oleh change order. Dari hasil tersebut maka dapat disimpulkan bahwa Ho ditolak dan Ha diterima.

2. Hipotesis 2

Ho = change order tidak berpengaruh signifikan terhadap mutu pada proyek konstruksi gedung bertingkat.

$\mathrm{Ha}=$ change order berpengaruh signifikan terhadap mutu pada proyek konstruksi gedung bertingkat.

Hasil analisis path modeling dapat dilihat pada Tabel 11 yang menunjukan nilai hubungan change order terhadap mutu sebesar 0,481 dan nilai T hitung mutu adalah sebesar 4,279 yang menandakan memiliki nilai yang lebih besar dari $\mathrm{T}$ tabel yaitu 1,96. Sehingga, T hitung > T tabel maka terjadi pengaruh signifikan terhadap mutu oleh change order. Dari hasil tersebut maka dapat disimpulkan bahwa Ho ditolak dan Ha diterima. 
3. Hipotesis 3

Ho = change order tidak berpengaruh signifikan terhadap waktu pada proyek konstruksi gedung bertingkat.

$\mathrm{Ha}=$ change order berpengaruh signifikan terhadap waktu pada proyek konstruksi gedung bertingkat.

Hasil analisis path modeling dapat dilihat pada Tabel 11 yang menunjukan nilai hubungan change order terhadap waktu sebesar 0,833 dan nilai T hitung waktu adalah sebesar 17,190 yang menandakan memiliki nilai yang lebih besar dari T tabel yaitu 1,96. Sehingga, T hitung > T tabel maka terjadi pengaruh signifikan terhadap waktu oleh change order. Dari hasil tersebut maka dapat disimpulkan bahwa Ho ditolak dan Ha diterima.

\section{KESIMPULAN DAN SARAN}

\section{Kesimpulan}

Berdasarkan dari hasil penelitian, maka peneliti memiliki kesimpulan bahwa pengaruh change order terhadap biaya adalah kurangnya biaya akibat dari penambahan item pekerjaan sehingga target yang sudah ada perlu disesuaikan kembali, sedangkan terhadap mutu adalah menurunnya kualitas bangunan akibat dari penambahan volume pekerjaan sehingga bahan yang digunakan perlu disesuaikan, dan terhadap waktu adalah terjadinya keterlambatan penyelesaian proyek akibat perubahan pekerjaan yang telah selesai.

\section{Saran}

Dari hasil penelitian yang telah dilakukan maka, dikemukakan beberapa saran berikut:

1. Pada Tabel 11 dapat dilihat hasil perhitungan nilai $\mathrm{T}$ hitung biaya adalah sebesar 4,237 , nilai $\mathrm{T}$ hitung mutu adalah sebesar 4,279, dan nilai T hitung waktu adalah sebesar 17,190. Penelitian ini menggunakan persentase kesalahan sebesar 5\% dengan nilai T tabel adalah sebesar 1,96 yang menandakan change order mempengaruhi secara signifikan terhadap biaya, mutu, dan waktu. Maka, penting dilakukan antisipasi bila terjadi change order agar kerugian-kerugian yang timbul dapat diminimalisir.

2. Bagi peneliti yang akan datang diharapkan untuk memperbanyak sampel dan menambahkan variabel indikator yang lebih banyak agar pengaruh change order yang teridentifikasi lebih banyak dan tepat sesuai kondisi nyata.

\section{DAFTAR PUSTAKA}

Barrie, Donald S. dan Boyd C. Jr. Paulson. Professional Construction Management (3rd Edition). Singapore: Mc Graw-Hill, 1992.

Diekmann, J. E. dan M. C. Nelson. “Construction Claims: Frequency and Severity.” Journal of Construction. Engineering and Management. ASCE (1985).

Ervianto dan Wulfram. Manajemen Proyek Konstruksi. Yogyakarta, 2002.

Fisk, Edward R. dan Wayne D. Reynolds. Construction Project Administration (8th Edition). New Jersey: Pearson Prentice Hall, 2006.

Ghozali, Imam. Structural Equation Modeling metode alternatif dengan PARTIAL LEAST SQUARES (PLS), Edisi 4. Semarang: Universitas Diponegoro Semarang, 2014.

Jr., Thomas J. Kelleher dan G. Scott Walters. Smith, Currie and Hancock's Common Sense Construction Law: A Practical Guide for the Construction Professional. Wiley, 2011.

Keane, P., B. Sertyesilisk dan A. D. Ross. "Variations and change orders on Construction Projects ." Journal of Legal affairs and Dispute Resolution in Engineering and Construction. ASCE (2010).

Levy, Sidney M. Project Management in Construction. New York: Mc Graw-Hill, 2002.

Sulistio, Hendrik dan Mega Waty. "Analysis and Evaluation Change order in Flexible Pavement (Case Study: Road Projects in East Kalimantan).” MEDIA KOMUNIKASI TEKNIK SIPIL, vol. 16, no. 1 (2008): 31-47.

Yadeta, Andualem Endris. "The Impact of Variation Order on Public Building Projects.” International Journal of Construction Engineering and Management (2016).

Zatika, Dinda Anna, Hamzah dan Depri Liber Sonata. "tinjauan yuridis perjanjian konstruksi pembangunan jalan tol antara Pt hutama karya (persero) dan Pt waskita karya (persero) Tbk.” pactum law jurnal (2018): 210. 